\title{
Analysis of the Deep Convective Activity over the Western Pacific and Southeast Asia
}

\section{Part II: Seasonal and Intraseasonal Variations during Northern Summer}

\author{
By Masato Murakami \\ Meteorological Research Institute, Ibaraki 305, Japan \\ (Manuscript received 10 September 1983, in revised form 2 December 1983)
}

\begin{abstract}
The seasonal and the intraseasonal behaviors of the deep convective clouds are investigated by using the activity index devised in Part I of this paper. The monthly mean distributions for the period from May through August 1979 have revealed many seasonal characteristics which have been inferred in the past from the cloudiness or from the outgoing longwave radiation (OLR). The latitudinal change of the distribution has clearly shown the northward advance of the convective area over the Southeast Asia, the formation of the highly convective area which brings the Bai-u (Mei-yu in Chinese) rain, and the northward shift of the convective belt associated with ITCZ over the western Pacific.

The latitude-time section of the above activity has revealed the existence of the major intraseasonal variation with the 30 - to 40-day periodicity. Over the Indo-China peninsula and the Bay of Bengal, it appears in the form of the repetitive progressions from the equatorial South Indian Ocean. The more detailed analysis using the band-pass filter has revealed that there also exists a southward-progressing component which comes down from the Tibetan Plateau. Moreover, it turned out that the similar situation also occurs over the western Pacific. The composite analysis performed on the wind variation at $850 \mathrm{mb}$ level verified that the above 30 - to 40-day variation is associated with the active/break cycle of the Indian monsoon. When the monsoon westerly is most intensified over India, the enhanced deep convection appears over the region ranging from the northeastern India to the Philippines. In contrast, the suppressed condition appears over the equatorial Indian Ocean and the Tibetan Plateau. Furthermore, it turned out that the convective activity associated with ITCZ is also intensified at this stage over the tropical western Pacific.
\end{abstract}

\section{Introduction}

Through the past decades, there has been a growing concern on the long-term variations of the tropical circulation system. One major topic of this problem is the interannual variation including the recently-emphasized $\mathrm{El}$, Nino/Southern Oscillation. (See Rasmusson and Carpenter, 1982 for its comprehensive description.) Another important aspect lies in the time-scale of seasonal- to intraseasonal variation. For many countries located within the monsoon region, the onset of monsoon and its dry/moist spell have a significant meaning not only in the meteorological sense, but also in the sense of socio-economic activity.
Since it is the amount of rainfall which mostly affects the human life in the monsoon region, many investigations have delt with the spatialand temporal variations of rainfall (see Ramage, 1971). When the data observed by the meteorological satellites came to use, scientists were quick to incorporate them in their studies of rainfall activity associated with the monsoon. In many of these literatures, satellite data were compiled either in terms of the cloudiness (Ramage et al., 1972; Sadler et al., 1976 and others) or in terms of the radiative values (Winston and Krueger, 1977 and others).

Concerning the time evolution of the Asian summer monsoon, T. Murakami (1976) examined the daily satellite cloudiness over the tropical 
belt during the northern hemispheric summer for the eight years 1965 to 1972 . He showed that the cloudiness changes over the monsoon region are positively correlated with those over the Malaysia-Indonesia region. $\mathrm{He}$ also found that the zone of either positive or negative correlation propagated northwards through the equatorial Indian Ocean and the Indian subcontinent. Based on these results, it was suggested that the phase reversal between active and break monsoons occurs as a part of the changes over a much more extensive area than just the immediate neighborhood of India. Asakura (1979) examined the cloud distribution over east Asia during the summer monsoon season. $\mathrm{He}$ also noted the existence of the cloud band which extends from the southeast Asia, covering south China and Japan during the summer rainy season.

T. Murakami (1980) also approached the major modes of intraseasonal oscillations present in the outgoing longwave radiation (OLR) during summer by means of the empirical orthogonal functions. He showed that the amplitude variations of the four largest eigenvectors exhibit marked periodicity of about 20 - to 30 days. In his composite analysis, the major mode appeared to propagate westward around $10-20^{\circ} \mathrm{N}$ and north ward over the South China Sea. Recently Cadet (1983) performed an analysis on the intraseasonal variation of the monsoon by using the surface observations over the Indian Ocean. His results also show the westward propagating mode with 20- to 40 day periodicity over the tropical Indian Ocean along with the northward propagating one over the eastern Indian Ocean. Krishnamurti and Subrahmanyan (1982) exhibited the synoptic sequences of the $850 \mathrm{mb}$ wind field. They showed that the train of troughs and ridges propagate northward over the Indian Ocean from the equator toward Himalayas.

The northward propagation mentioned above was intensively investigated by Yasunari (1979) and Sikka and Gadgil (1980) in terms of the cloudiness change. They found that it occurs with the time interval of $30-$ to 40 days and it is closely associated with the active/break phase of the Indian summer monsoon. Yasunari (1979) also pointed out that a simultaneous northward movement takes place over the whole Asian monsoon area rather than just the vicinity of India. In his further investigations, Yasunari $(1980,1981)$ has revealed that the above suturation appears almost every year from 1966 through 1973. Evidences were also discussed as to the possible interaction between the Asian monsoon area and the middle latitude of the southern hemisphere.

From the investigations mentioned above, it emerges that the large-scale distribution of the convective activity should also be changed by the 30 - to 40 day intraseasonal variation as well as by the seasonal evolution during the early summer. It is very likely that the individual regional changes of the convective activity form an integrated system over the southeast Asia and the western Pacific. In the Part I of this paper (Murakami, 1983), the author defined the intensity index of the convective activity in terms of the mean cloud top height of the convective clouds themselves. It was tried to reduce the meteorological ambiguity which was inherent in the use of the areal cloudiness or the areally averaged OLR values. In the Part $I$, it was shown that the above index can properly describe the diurnal convection both over the land and the sea.

In the present paper, we shall apply the above index to investigate the long-term behavior of the convective activity. Section 2 briefly reiterates the definition of the index and the data source. In Section 3, we shall discuss the seasonal evolution from May through August. Section 4 will describe the characteristic behavior of the large-scale aspect of the convective activity associated with the 30 - to 40 day intraseasonal variation.

\section{Data and method of analysis}

Investigation of the deep convective cloud system was carried out by using infrared (IR) data. These data were observed by GMS-1 geostationary satellite which was located at $\left(0^{\circ}\right.$, $140^{\circ} \mathrm{E}$ ). We have taken four months (May through August) from the observation during 1979 in order to examine the variations during northern hemispheric summer. During this period, the 3-hourly IR observations (about $5 \mathrm{~km}$ in spatial resolution) were edited in terms of the equivalent black body temperature $\left(T_{B B}\right)$ over every $1^{\circ}$ longitude-latitude square mesh.

Based on the above $T_{B B}$ distribution on each $1^{\circ}$ square mesh, we have picked up the convectively active mesh and estimated its intensity $I_{c}$ in the same manner as Part I of this paper. Although we do not repeat the detailed discussion here, the intensity index $I_{c}$ was defined as, 


$$
I_{c}=\frac{\bar{T}_{B B}-T_{400}}{T_{t r}-T_{400}} \times 10
$$

where $\bar{T}_{B B}^{c}$ represents the mean cloud top temperature which penetrates above $400 \mathrm{mb}$ level. $T_{t r}$ and $T_{400}$ represent the atmospheric temperature at the tropopause- and $400 \mathrm{mb}$ levels, respectively. One can see that the value of $I_{c}$ represents the mean cloud top height over the $1^{\circ}$ square mesh measured by the temperature difference between the tropopause and the 400 $\mathrm{mb}$ level. For instance, if all the cumuli are shallow and reach only up to $400 \mathrm{mb}$ level, the value of $I_{c}$ is zero, because $\bar{T}^{c}{ }_{B B}=T_{400}$ in that situation. On the other hand, $I_{c}$ becomes 10 if all the cumuli reach tropopause level. We shall use this $I_{c}$ as a measure of the deep convective activity. For further details of this index, the reader may refer to the Part $I$ of this paper.

Recently we have also acquired FGGE level III-b data set produced by the European Centre for Medium Range Weather Forecasts (ECMWF). Since the main part of FGGE (First GARP Global Experiment) was conducted in the same year 1979, we have incorporated this data set to examine the large-scale atmospheric motion at the various stages of the convective activity.

\section{Seasonal evolution}

\subsection{Monthly mean horizontal distributions}

To start with, we shall examine the seasonal evolution during the early summer of 1979 on the month to month basis. Figs. 1a through $1 \mathrm{~d}$ represent the horizontal distributions of the monthly mean values of $I_{c}$ for May through August 1979. The diagram also represents the area of analysis in this study. Shaded area denotes the region where the mean value is greater than 2.0. Following the definition in the previous section, the area with large $I_{c}$ indicates the frequent occurrence of the deep convective clouds over the same area.

In May 1979 shown in Fig. 1a, one can see the active area of the deep convection over the Indo-China region, in the vicinity of Philippines and over the equatorial western Pacific to the northeast of New Guinea. The intense mean activity over the western coast of Indo-China indicates that the rainy season has already started over this region in May, well in advance of the onset of the Indian summer monsoon. The premonsoon situation over India can be also inferred from the relatively small mean values of $I_{c}$ over the head Bay of Bengal and the northeast India.
Fig. 1a also shows that the wide area with low convective activities appears over the western Pacific to the north of about $10^{\circ} \mathrm{N}$. It indicates the prevalence of the subtropical anticyclone over the same area. Surrounding this area, we can see the existence of the convective belts to the southeast of Japan and to the north of the equator. The location of the former belt corresponds to the frontal zone during the preBai-u (rainy season in Japan) stage discussed by Yoshino $(1965,1966)$. He has shown that the above zone shifts northward during June through July. We shall also see the similar situation in terms of the convective activity in the latter half of this section.

The east-west oriented convective belt over the equatorial Pacific appears to show the activity associated with the intertropical convergence zone (ITCZ). It is of interest to see that the distribution reveals the two parallel convective belts to the north and to the south of the equator over the central equatorial Pacific east of $160^{\circ} \mathrm{E}$. This situation well agrees with Yoshino (1971)'s climatological analysis in which he showed the typical location of ITCZ over the western Pacific and discussed the existence of the north- and south ITCZ on both sides of the equator.

The monthly mean distribution of the convective clouds in June are exhibited in Fig. 1 b. This month is characterized by the onset of the Indian summer monsoon and also by the onset of Bai-u in Japan. In 1979, the onset of monsoon over the southern part of India was declared on 12 June by the India Meteorological Department and the Bai-u began around 6 June. Keeping pace with the onset of these rainy periods, the intense convective activity takes place over the head Bay of Bengal. From there the area of the high convective activity extends northeastward across the southern part of China, the East China Sea and the southwestern part of Japan. This distribution represents the typical configuration of the deep convective clouds during the rainy season over the East Asia including the Bai-u in Japan.

In Fig. 1b, one can also see the substantial intensification of the deep convection over the western Pacific. The high convective activity appears over the Philippines including the eastern portion of the South China Sea. It forms a convective belt over the western Pacific extending east-southeast toward the central Pacific. To the east of $160^{\circ} \mathrm{E}$ over the equatorial Pacific, 
the distribution again indicates the double convective belts on both sides of the equator as we have seen in the previous figure. Comparing the location of this equatorial convective belt in May and June, we can see that the belt to the east of $160^{\circ} \mathrm{E}$ remains nearly at the same latitude, while it considerably shifts northward to the west of $140^{\circ} \mathrm{E}$. It is also noteworthy that the Java Sea and Banda Sea regions to the south of Borneo and Celebes show the decrease of the convective activity from May to June. Arakawa (1959) pointed out in his earlier investigation that the start of the rainy season in Japan is closely related to the start of the dry season in Java as well as to the start of the southwest monsoon in India. The present situation in the deep convective activity seems to provide another clue to confirm his finding.

Fig. 1c represents the monthly mean distribution of the deep convective clouds in July 1979. The southwest monsoon in 1979 over India advanced up to the northeastern part of the country by 30 June (FGGE Operations Report No. 8, 1981). Reflecting the consequence of this

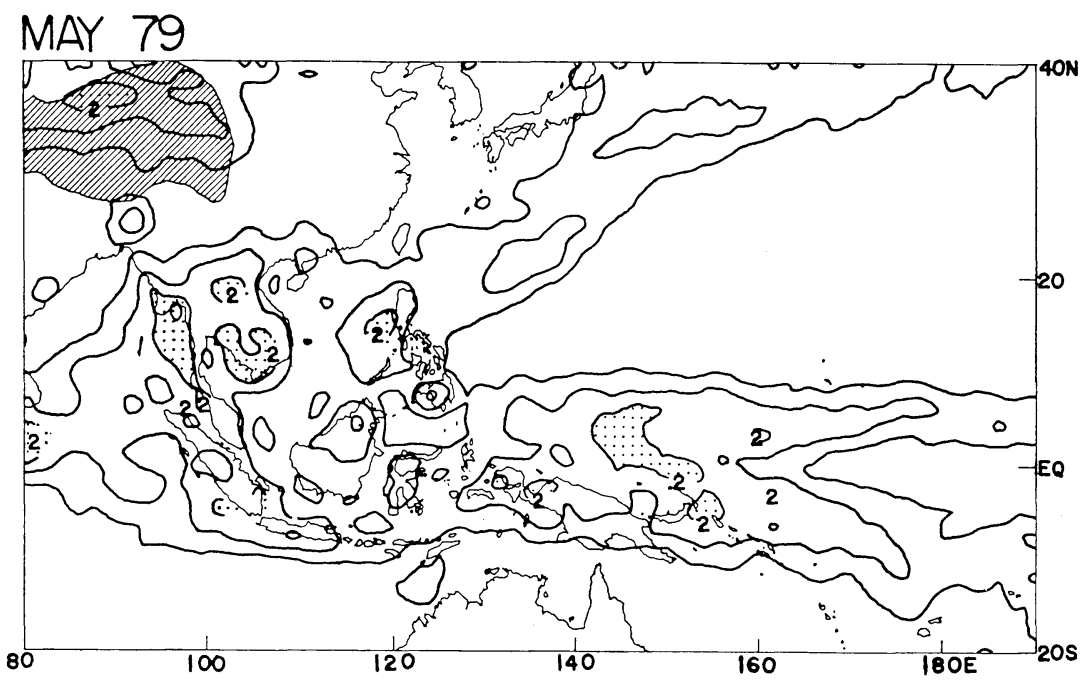

(a)

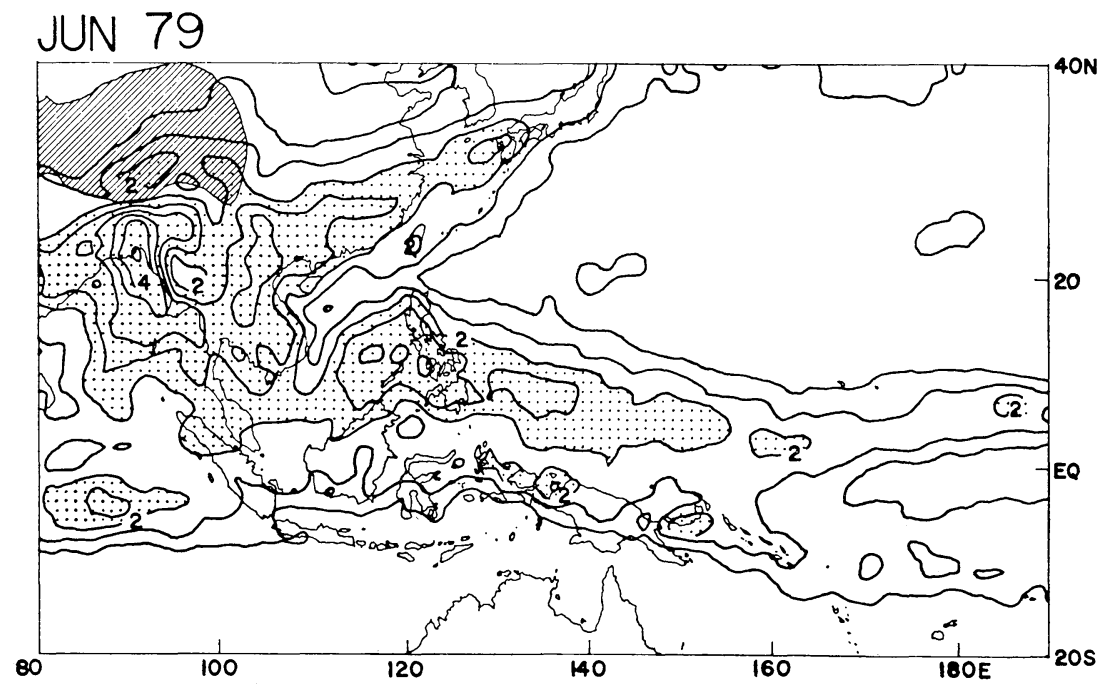

(b)

Fig. 1 (Continued) 


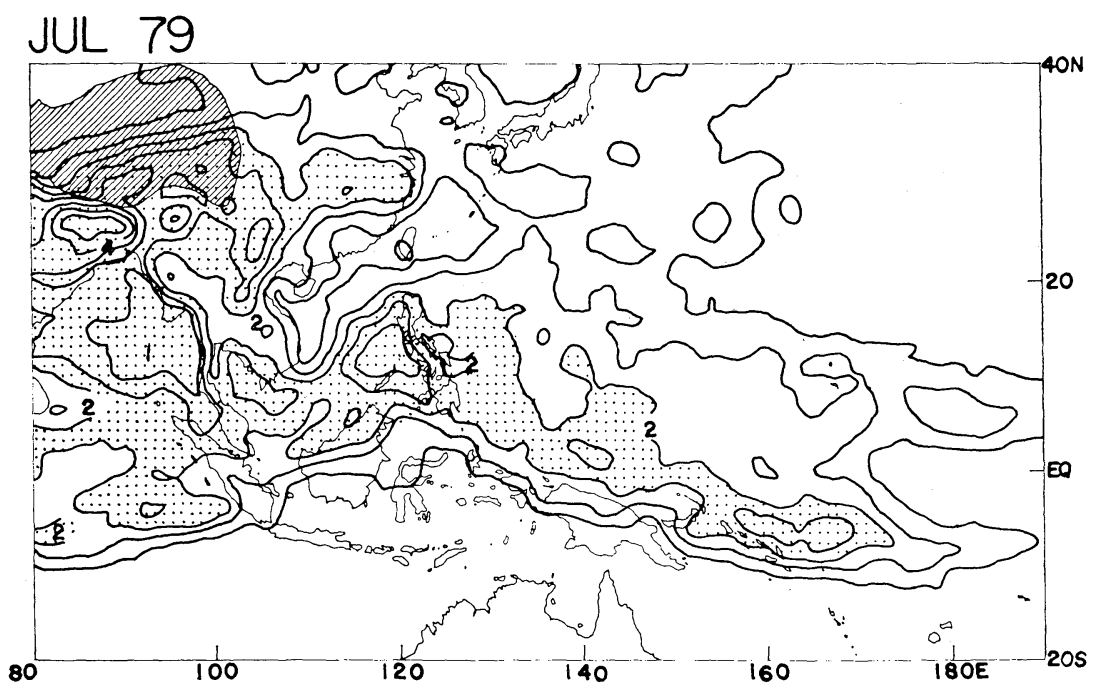

(c)

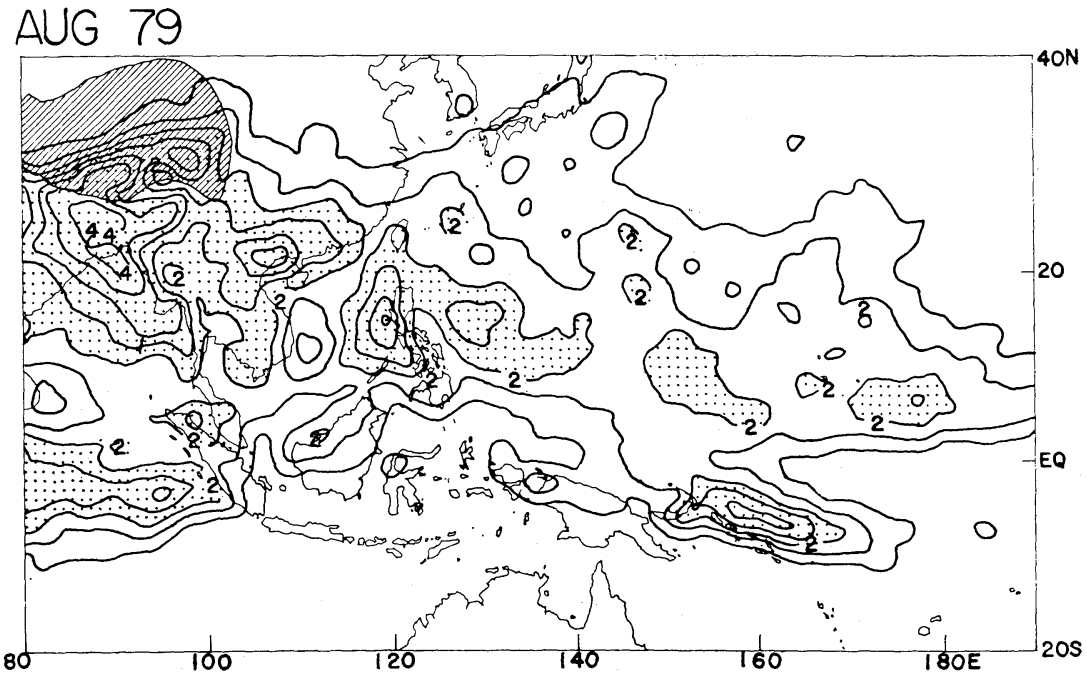

(d)

Fig. 1 Horizontal distributions of monthly mean values of $I_{c}$ for May (a) through August (d) 1979. Contours are drawn at every 0.5 units starting from 1.0. Values greater than 2.0 are shaded. Hatched area roughly denotes Tibetan Plateau above $3,000 \mathrm{~m}$ in elevation.

seasonal evolution, the intense convective ac- tion seems to result from the characteristic betivity in July takes place over the northeast havior of the so-called "Bai-u front" over the India ranging from the head Bay of Bengal up East China Sea-Japan area. It is known that to the southeastern part of Tibetan Plateau. The the Bai-u front and its associated rainfall beintense convection also persists over the southern come increasingly migratory in July and start China, but it becomes ill-difined over the East moving northward. The wide-spread distribution China Sea and the southwestern part of Japan. of the convective activity over the area ranging Instead, these area show the wide-spread dis- from northern Korea to Japan seems due to tribution of the convective activity. This situa- this north-south migration of the convective sys- 
tem in July.

Fig. 1c also shows the intense convective activity over the eastern part of South China Sea close to the Philippines. From there, a convective belt extends east-southeast and reaches the area close to Solomon Islands in the equatorial South Pacific. Comparing the location of this belt with that of June in the previous figure, it appears that the southern branch of ITCZ was more active than the northern one in July. Since the past climatological studies generally show that the northern branch of ITCZ becomes intensified from May to August, the present result may represents one of the anomalous features in the year of 1979.

Another interesting situation in Fig. 1c appears over Indo-China and South China Sea. It is notable that the convective activity is weak to the east of Burmese mountains which range roughly along $100^{\circ} \mathrm{E}$ meridian. The activity is also weak off the east coast of Indo-China to the east of Vietnamese mountains. One can see that these regions coincide with the lee-side of the large-scale mountains within the prevailing low-level monsoon westerlies in July. Considering this, the situation mentioned above seems to reveal the influence of the large-scale orography on the distribution of the deep convective clouds.

During August 1979 exhibited in Fig. 1d, the intense convective activity persists over the head Bay of Bengal through the southeastern part of the Tibetan Plateau. However, the convectively active area over China has withdrawn southward from its position in July. It can be seen that the activity has diminished over the northern China and Korea. It indicates that the rainy reason is over in this area. On the other hand, the area around the Philippines and the area to the east of Solomon Islands persistently show the high convective activity through July and August. However, in August, it is obvious that the activity is widely intensified over the western Pacific to the north of $5^{\circ} \mathrm{N}$. This intensification of the convective activity is reflected in the number of tropical depressions and typhoons which are formed in the tropical western Pacific. According to the Geophysical Review 1979 published by Japan Meteorological Agency, the total number of depressions and typhoons formed to the west of $160^{\circ} \mathrm{E}$ was 4 in July, while it was doubled to 8 in August.

\subsection{Changes in the latitudinal distribution}

Through the analysis of the horizontal pattern discussed above, it becomes clear that the significant seasonal change occurs in the distribution of deep convective clouds over the Southeast- to East Asia and over the western Pacific. We have also seen that the above seasonal evolution often manifests itself in the form of the northsouth displacement of the convective activity. In this subsection, we shall look into such latitudinal aspect over the above-mentioned regions. A digital low-pass filter was applied to the original 3-hourly time series of $I_{c}$ in order to pick up the seasonal change discussed in the previous subsection. Fig. 2 shows its response as a function of the period. It can be seen that the filter excludes the variation with the period shorter than 10 days, while it retains the seasonal time-scale and the long-term, intraseasonal variation with the period longer than 20 days.

Fig. 3 represents the latitude-time section of the filtered values of $I_{c}$ averaged over the longitudes from $90^{\circ} \mathrm{E}$ through $100^{\circ} \mathrm{E}$. This meridional belt runs through the South Indian Ocean, western part of Sumatra $\left(\sim 0^{\circ} \mathrm{N}\right)$, Malay Peninsula $\left(\sim 10^{\circ} \mathrm{N}\right)$, Burma $\left(\sim 20^{\circ} \mathrm{N}\right)$ and the southeastern part of Tibetan Plateau $\left(\sim 30^{\circ} \mathrm{N}\right)$. It also includes the eastern half of the Bay of Bengal from $0^{\circ} \mathrm{N}$ through $20^{\circ} \mathrm{N}$. The shaded area in the diagram denotes the latitudes where the relatively deep convective clouds take place.

At the beginning of May 1979, the major convective area was confined to the south Bay of Bengal to the south of $10^{\circ} \mathrm{N}$. As the time went on, this convective zone moved northward and reached the southeastern Tibet around the middle of June. The timing of this movement well agrees with the onset of the monsoonal season over the western coast of Indo-China (FGGE Operations Report No. 8, 1981). After

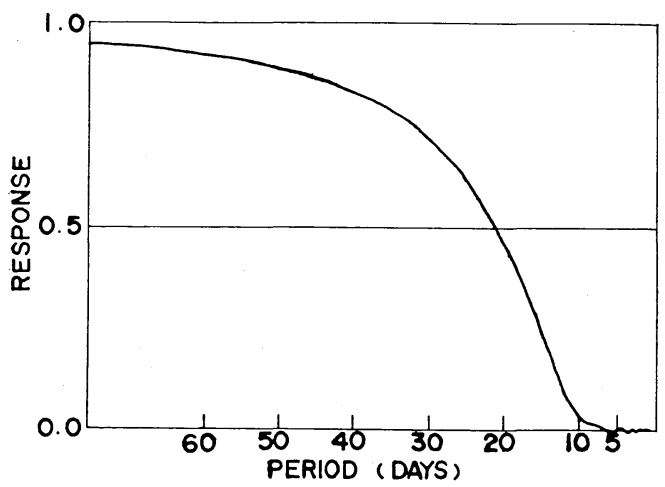

Fig. 2 Response of the lowpass filter used in this study. 


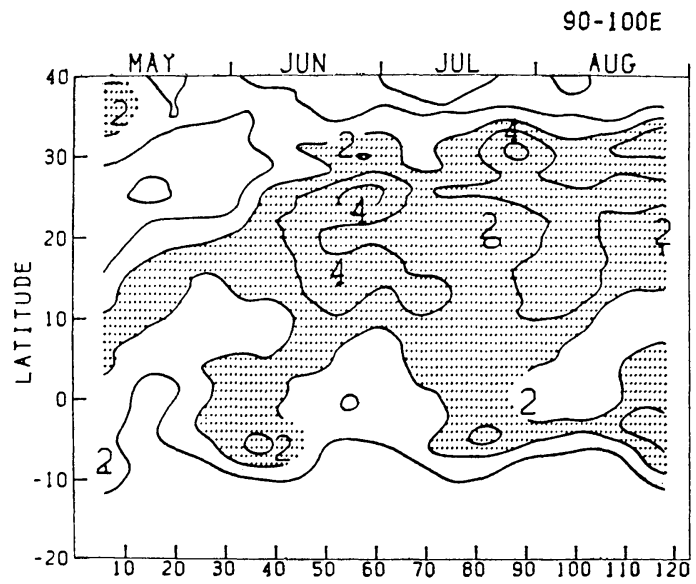

Fig. 3 Latitude-time section of the lowpassfiltered values of $I_{c}$ averaged over the longitudes from $90^{\circ} \mathrm{E}$ through $100^{\circ} \mathrm{E}$. Contour interval is 1.0 and the values greater than 2.0 are shaded. Numbers in the abscissa denote the days from the beginning of May 1979.

the convective area passed the $30^{\circ} \mathrm{N}$ around the middle of June, the northward movement came to a halt. Instead, the convective activity started showing major fluctuations to the south of $35^{\circ} \mathrm{N}$. Through July and August, it can be seen that the northern limit of the deep convection stays around $35^{\circ} \mathrm{N}$. It indicates that the deep convective clouds generally take place over the southern portion of the Tibetan Plateau and to the south of it.

Another interesting behavior of the deep convective clouds in Fig. 3 is their repetitive northward progression during May through August. The first progression which occurred in May marked the onset of the rainy reason over IndoChina as discussed above. However, one can see that at least two more progressions took place over the same area in June and July. Both of them start at the South Indian Ocean around $5^{\circ} \mathrm{S}$ and progress northward with a phase speed of about $1^{\circ}$ latitude/day. This behavior coincides very closely with the one appearing in the cloudiness change reported by Yasunari (1979). We shall examine it in more detail in the next section.

Fig. 4 shows the latitude-time section of the filtered values of $I_{c}$ averaged over the longitudes from $120^{\circ} \mathrm{E}$ through $130^{\circ} \mathrm{E}$. This meridional belt represents the situation over the western Pacific off the east coast of Asian continent. It runs through the northwestern coast of Australia

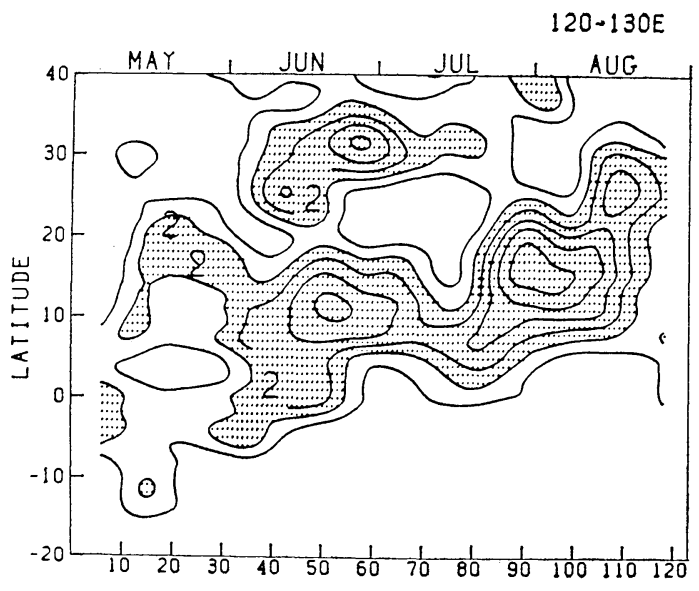

Fig. 4 Same as Fig. 3 except for the longitudes from $120^{\circ} \mathrm{E}$ through $130^{\circ} \mathrm{E}$. Contours are drawn at every 0.5 units and the values greater than 1.5 are shaded.

$\left(\sim 20^{\circ} \mathrm{S}\right)$, Indonesian Islands $\left(\sim 0^{\circ} \mathrm{N}\right)$, the Philippines $\left(\sim 15^{\circ} \mathrm{N}\right)$, East China Sea $\left(\sim 30^{\circ} \mathrm{N}\right)$ and Korea $\left(\sim 40^{\circ} \mathrm{N}\right)$. One of the notable features in this figure is that the intense convective areas are formed separately during the early summer. The northern one appeared over the East China Sea during June through July 1979. This convective activity corresponds to the Bai-u rain over East Asia. When one examines its latitudinal behavior more closely in Fig. 4, it can be seen that the major intensification of the activity first occurred at the latitude around $25^{\circ} \mathrm{N}$, close to Taiwan, at the beginning of June. This period coincides with the time when the intense convective area over Indo-China also reached the same latitude in the previous figure. It seems to suggest that the arrival of the southwest monsoon at the head Bay of Bengal also marks the onset of Bai-u over East Asia.

After its appearance in early June, the convective area close to Taiwan moved northward and reached the latitude around $30^{\circ} \mathrm{N}$ at the end of the month. It was during this period that southwestern Japan suffered severe rainstorms which caused flash floods in many places. In the middle of July, the convective activity was somewhat weakened, but the active area started moving northward again toward the end of this month. At the beginning of August, the convective area was located over Korea around $40^{\circ} \mathrm{N}$. It can be seen that the activity was diminished over the area around $30^{\circ} \mathrm{N}$, indicating the end of the rainy Bai-u season.

In Fig. 4, one can also see the intense con- 
vective activity over the tropical- to subtropical regions. At the very beginning of May 1979, it was located over Indonesian Islands just to the south of the equator. However, nearly at the same time when the Bai-u started in the early June around $25^{\circ} \mathrm{N}$, a major intensification of the convective activity took place to the north of the equator around $10^{\circ} \mathrm{N}$. It corresponds to the appearance of the ITCZ over the western Pacific to the east of the Philippines as we have seen in Fig. $1 \mathrm{~b}$ in the previous subsection.

Thus, during June through July, we see two convective areas around $30^{\circ} \mathrm{N}$ and $10^{\circ} \mathrm{N}$. We can also see the area where the deep convective clouds are suppressed in between. The northern convective area represents the so-called "Bai-u front" and the southern one is associated with the ITCZ over the western Pacific. The convectively suppressed area around $20^{\circ} \mathrm{N}$ is due to the existence of the subtropical anticyclone. This suppressed area shifts its position northward from July to August, bringing stable summer weather to Japan and Korea. It is of interest to see that the northward progression of the Bai-u front at the end of July coincides closely with the northward expansion of the deep convective clouds over the tropical western Pacific. It seems to suggest that the onset and the end of the Bai-u season are also linked with the northward migration of ITCZ over the western Pacific.

\section{Intraseasonal variation}

In the previous section, we have examined the seasonal evolution of the deep convective clouds in terms of their horizontal distribution and their latitudinal behavior. Through the latter discussion one may also have noticed that the seasonal evolution is by no means monotonous. Superposed on the seasonal trend from May to August, a major fluctuation of the convective activity was seen in the time sequence. The time-scale of the fluctuation appeared to be about one month or so. In this section, we shall look into this intraseasonal variation of the deep convective activity.

As we can estimate from the previous time sequences, the characteristic periodicity of the major intraseasonal variation appears to be about 30 days. Yasunari $(1979,1980)$ 's spectral analysis shows that the spectral peak around 30 - to 40 day period is dominant in the cloudiness fluctuation over the Asian monsoon area. Here, we shall examine whether the above

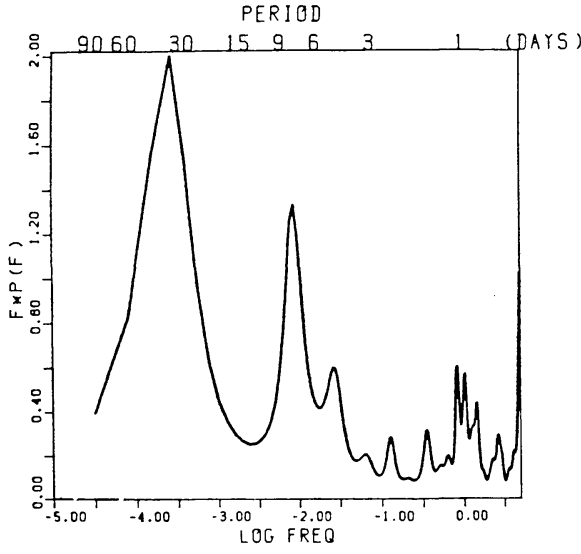

(a)

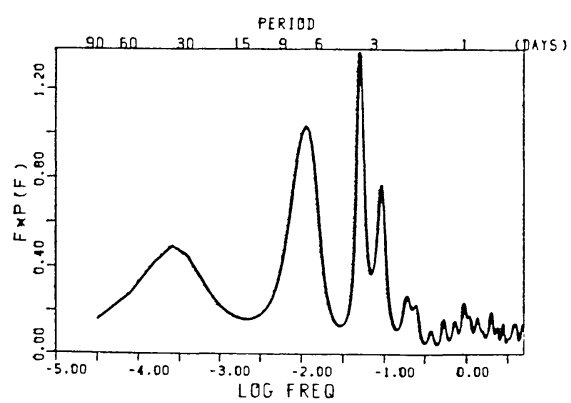

(b)

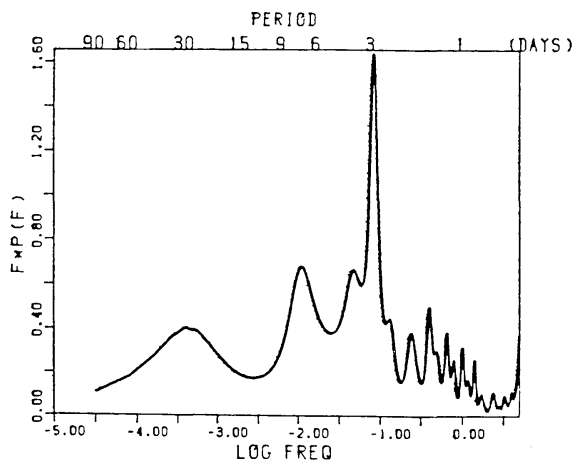

(c)

Fig. 5 Power spectra of $I_{c}$ over the South China Sea (a), western Pacific (b), and central equatorial Pacific (c) for the period from May 1 through August 31, 1979. The ordinate denotes the product of the frequency and the power spectral density. The abscissa denotes the log frequency and the corresponding period. See text for further details.

periodicity also appears over the western Pacific and its vicinity. Figs. 5a through $5 \mathrm{c}$ represent the power spectra of $I_{c}$ averaged over the South China Sea $\left(115^{\circ}-120^{\circ} \mathrm{E}, 10^{\circ}-15^{\circ} \mathrm{N}\right)$, over the 
western Pacific $\left(130^{\circ}-135^{\circ} \mathrm{E}, 10^{\circ}-15^{\circ} \mathrm{N}\right)$ and over the central equatorial Pacific $\left(175^{\circ}-180^{\circ} \mathrm{E}\right.$, $5^{\circ}-10^{\circ} \mathrm{N}$ ), respectively. Over the South China Sea shown in Fig. 5a, the spectral peak at about 30 - to 40 day period appears as the most dominant one. The secondary peak appears at the period around 7 days. We can also see the concentration of the spectral power at the diurnal period though the peak is not very welldefined. Over the western and the central equatorial Pacific exhibited in Figs. $5 b$ and $5 c$, the most prominent spectral peak appears around 3 - to 4 day period. As the secondary peak, one can pick up the spectral power around 7- to 9 day period. These peaks are presumably due to the passage of the synoptic-scale, tropical disturbances. However, what draws our interest is the fact that we can clearly recognize the spectral peak at 30 - to 40 day period in these diagrams as well. It indicates that the 30 - to 40 day periodicity in the convective activity does appear over the wide range from the Asian monsoon region to the central equatorial Pacific as characteristic mode of the intraseasonal variation.

In order to examine the above-mentioned intraseasonal variation specifically, a digital bandpass filter was applied to the original time series. Fig. 6 represents its response as a function of the period. The filter was made based on the recursion technique described in Murakami (1979). Its response was designed in such a way that the filter can retain the oscillation with the period around 30 to 40 days. The response function in Fig. 6 shows that the present filter excludes the oscillation with the period longer than 50 days and the one shorter than 20 days, retaining less than $50 \%$ of the amplitudes.

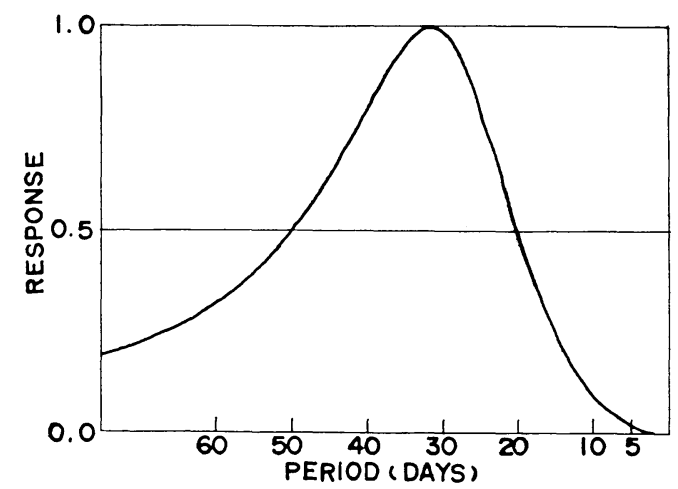

Fig. 6 Response of the bandpass filter used in this study.

\subsection{Changes in the latitudinal/longitudinal distributions}

Figs. $7 \mathrm{a}$ and $7 \mathrm{~b}$ represent the latitude-time section of the bandpass-filtered anomalies of $I_{c}$ averaged over the longitudes from $90^{\circ} \mathrm{E}$ through $100^{\circ} \mathrm{E}$ and from $120^{\circ} \mathrm{E}$ through $130^{\circ} \mathrm{E}$, respectively. These longitudes are equivalent to those adopted in Fig. 3 and Fig. 4 in the previous section. The shaded area in the diagram denotes the positive anomalies, indicating the enhanced convective activity due to the $30-$ to 40 day mode. Comparing Fig. 7a with Fig. 3, one can see that the 30-to 40 day mode in the former figure accounts for many aspects of the intraseasonal variation which appears in the latter figure. Especially the repetitive northward progression of the convective area previously discussed in Fig. 3 appears as a major characteristic feature of the 30- to 40 day mode in Fig. 7a. The distribution of the anomalies in this figure reveals that the progression generally starts at the Indian Ocean just to the south of the equator and proceeds with the nearly constant phase speed i.e. around $1^{\circ}$ latitude/day. In addition, it also reveals the evidence of the southward progression of the convectively active area coming down from the Tibetan Plateau. Both progressions tend to meet at around $20^{\circ} \mathrm{N}$, the latitude close to the head Bay of Bengal.

As for the amplitude of the 30- to 40 day, intraseasonal variation, Fig. 7a seems to show three local maxima. The southernmost one appears over the Indian Ocean just to the south of the equator over the latitudes from $0^{\circ}$ to $10^{\circ} \mathrm{S}$. The northern one appears around $30^{\circ} \mathrm{N}$, corresponding to the southeastern part of the Tibetan Plateau. In between one can also see the other region which lies over the latitudes from $10^{\circ} \mathrm{N}$ through $20^{\circ} \mathrm{N}$. These latitudes correspond to the Bay of Bengal including the western coast of Indo-China. As for their phase relationship in Fig. 7a, it appears that the variation over the Bay of Bengal is out of phase to that over the South Indian Ocean (SIO). It indicates that the convective activity over SIO tends to be enhanced when it is suppressed over the Bay, a well-known characteristic feature during the break monsoon over India. Besides, Fig. 7a also shows that the variations over SIO is nearly in phase with that over the Tibetan Plateau ranging from $30^{\circ} \mathrm{N}$ through $40^{\circ} \mathrm{N}$. Thus the intraseasonal behavior of the deep convective activity over India through Indo-China region can be also characterized by the in-phase rela- 


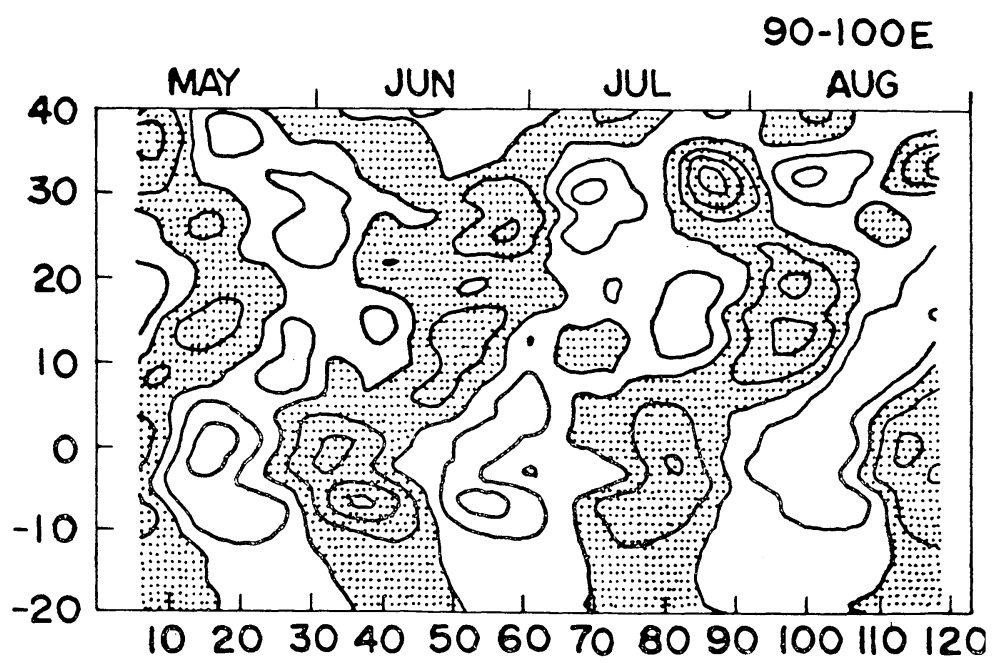

(a)

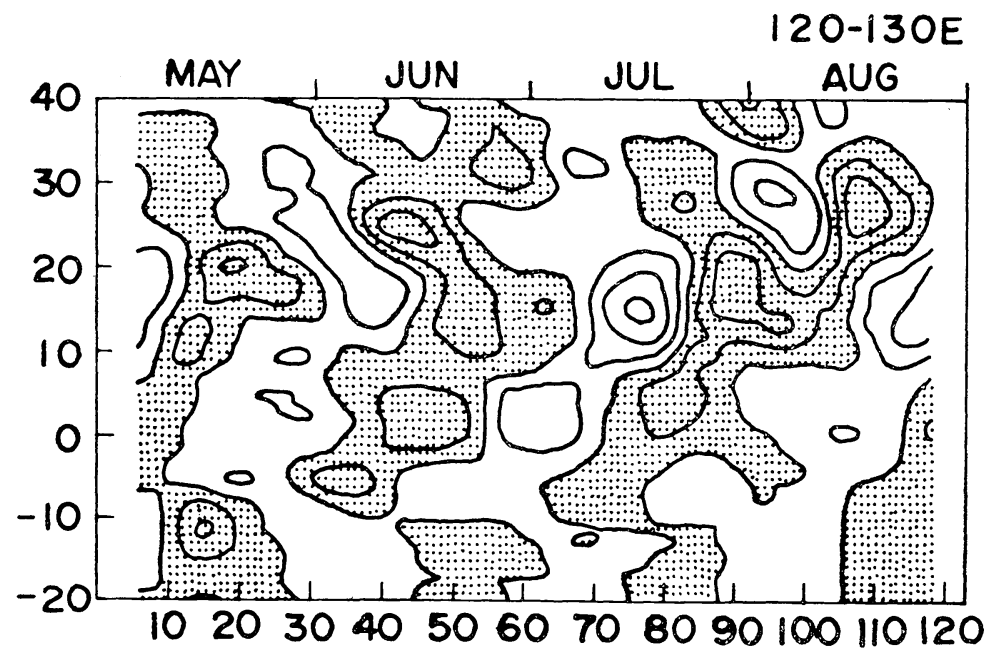

(b)

Fig. 7 Latitude-time section of the bandpass-filtered anomalies from the time mean of $I_{c}$ averaged over the longitudes from $90^{\circ} \mathrm{E}$ through $100^{\circ} \mathrm{E}$ (a) and from $120^{\circ} \mathrm{E}$ through $130^{\circ} \mathrm{E}$ (b). Contours are drawn at every 0.4 units and the positive anomalies are shaded. Numbers in the ordinate denote latitude (negative for southern hemisphere) and those in the abscissa denote the days from the beginning of May 1979.

tionship between SIO and Tibetan Plateau along with the out-of-phase variation over the Bay of Bengal.

Fig. 7b represents the latitude-time section of the bandpass-filtered anomalies of $I_{c}$ over the western Pacific. This diagram represents the situation over the same area as the previous Fig. 4. In Fig. 4, we saw the major seasonal evolution of the convective cloud system associated with the Bai-u front and the ITCZ. Here, in Fig. $7 \mathrm{~b}$, we shall see the different aspect accompanying the intraseasonal variation. Most 
notable in this figure is the fact that the repetitive northward progression also takes place over the western Pacific. It appears to start at the latitude just to the south of the equator and can be traced up to around $20^{\circ} \mathrm{N}$. This starting latitude is nearly the same as the one we saw in Fig. 7a. Furthermore, by comparing Fig. 7a with $7 \mathrm{~b}$, it can be seen that the timing of the northward progressions almost coincides with each other.

In addition to the northward progression mentioned above, Fig. $7 \mathrm{~b}$ also reveals the clear evidence of the southward progression of the deep convective system. It starts at the latitudes north of $30^{\circ} \mathrm{N}$ and meets with the northward progressing system at around $15^{\circ} \mathrm{N}$ to $20^{\circ} \mathrm{N}$. Comparing this situation with the one in Fig. $7 \mathrm{a}$, it appears that the latitude of confluence is located slightly southward in Fig. 7b. However, the timing of both progressions of Figs. 7a and $7 b$ are again very close with each other.

The above results on the latitudinal behavior of the intraseasonal variation all indicate the inter-regional characters of the associated convective systems. Along the meridian running through the Tibetan Plateau to SIO, we saw the repetitive northward progression which corresponds to the one discussed by Yasunari (1979) and Sikka and Gadgil (1980). Moreover, this study has revealed that there also exists a southward progression coming down from the middle latitude. Yasunari (1979) also noted the existence of the southward component over the southeast Asia though his main emphasis was put on the northward progression. The confirmation of the southward component in this study suggests that both northward- and southward progressions constitute the total aspect of the 30- to 40 day cycle of the deep convective activity. These northward- and southward progressions are also found over the western Pacific as well. Besides, it turned out that the progressions in these separate regions bear close time coincidence with each other. This coincidence may indicate that the 30 - to 40 day mode of the convective activity bears the longitudinally in phase character rather than the travelling nature in the subtropical latitudes over the east Asia.

The major area in which we can notice longitudinal differences between Fig. $7 \mathrm{a}$ and $7 \mathrm{~b}$ appears over the tropical latitudes around the equator. Fig. 8 represents the longitude-time section of the bandpass-filtered anomalies of $I_{c}$ averaged over the latitudes from the equator to

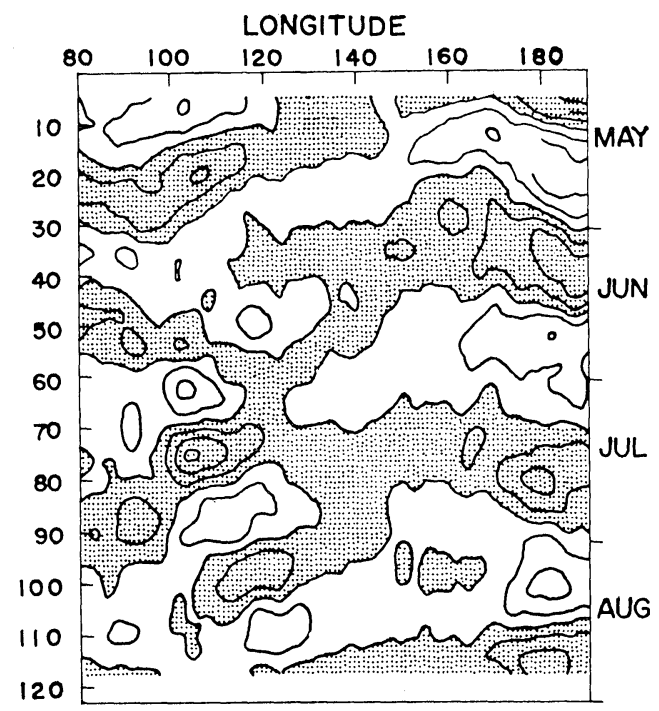

Fig. 8 Longitude-time section of the bandpass filtered anomalies of $I_{c}$ averaged over the latitudes from the equator to $10^{\circ} \mathrm{S}$. Contours are drawn at every 0.4 units and the positive anomalies are shaded. Numbers in the ordinate denote the days from the beginning of May 1979.

$10^{\circ} \mathrm{S}$. The shaded area in the diagram denoted positive anomalies. This longitudinal belt runs through SIO $\left(80^{\circ}-100^{\circ} \mathrm{E}\right)$, Indonesian Islands $\left(100^{\circ}-150^{\circ} \mathrm{E}\right)$ and the equatorial Pacific (east of $\left.150^{\circ} \mathrm{E}\right)$. This figure clearly indicates that the 30 - to 40 day mode of the convective activity shows the longitudinal propagation along the equator. In addition, it can be noticed that there are two separate regions which show different characteristics of the longitudinal propagation. To the east of $160^{\circ} \mathrm{E}$, the 30 - to 40 day mode tends to show the eastward propagation toward the central Pacific. This characteristic feature agrees with Maruyama (1982)'s analysis in which he showed that the $30-$ to 50 day mode in the equatorial upper tropospheric wind propagates eastward mainly over the region east of $140^{\circ} \mathrm{E}$. On the other hand, over the region to the west of $140^{\circ} \mathrm{E}$, we can see the tendency of the westward propagation although the occasional eastward component can be also noticed. Considering these aspects along with the geographical location, it emerges that the 30- to 40 day mode tends to show the eastward propagation along the equator to the east of Indonesian Islands, while it tends to propagate westward over Indonesia and to its west. 
The above situation makes clear contrast to that in the subtropical latitudes where the longitudinally simultaneous progression takes place in the north-south direction. The co-existence of these different characteristics suggests that the intraseasonal variation of the summer monsoon should be viewed as a part of complex, interregional changes as pointed out by T. Murakami (1976) earlier. In the following discussions, we shall look into this aspect by means of the composite analysis.

\subsection{Composited horizontal distributions}

In order to perform a composite analysis, we have to pick up some reference time series. Such time series should bear (1) a sufficiently large amplitude of the variation to be analyzed and (2) well-defined peaks to be pinpointed in order to classify each cycle of the variation into several categories. Taking these requirements into account, we have selected the filtered variation over the equatorial SIO as a reference time series. Figs. $9 a$ and $9 b$ exhibit this time series in terms of the original 3-hourly values of $I_{c}$ and their bandpass-filtered anomalies from the time mean value, respectively. The values are spatially averaged over $10^{\circ}$ longitude/latitude square area ranging from $90^{\circ} \mathrm{E}$ to $100^{\circ} \mathrm{E}$ and from $0^{\circ}$ to $10^{\circ} \mathrm{S}$. This area was selected so that the corresponding temporal variation can be also seen in Fig. 7a and Fig. 3 as well.

The original time series in Fig. 9a already shows the existence of the long-term, intraseasonal variation of the deep convective activity with the time-scale of a month or so. It is

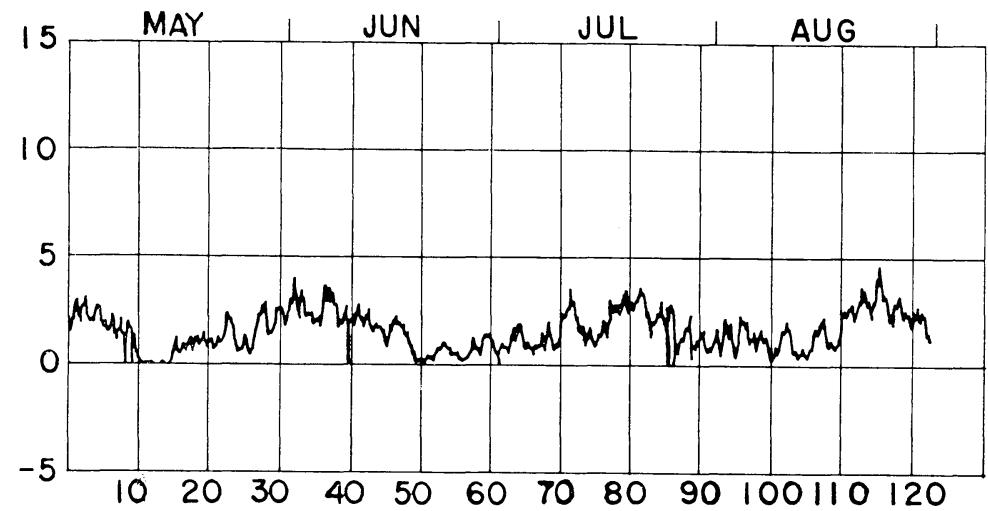

(a)

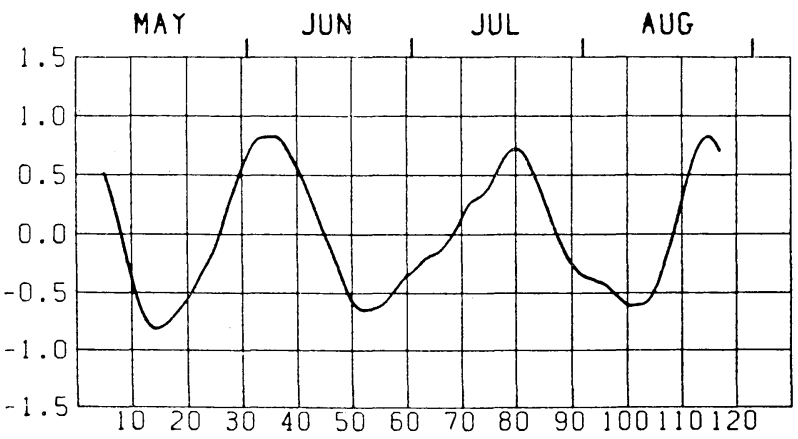

(b)

Fig. 9 Temporal variation of the 3-hourly values of $I_{c}$ (a) and their bandpass-filtered anomalies (b) averaged over the area extending from $0^{\circ}$ to $10^{\circ} \mathrm{S}$ in latitude and from $90^{\circ} \mathrm{E}$ to $100^{\circ} \mathrm{E}$ in longitude. The abscissa represents the days from the beginning of May 1979. 
modulated by the shorter term fluctuations ranging from diurnal to several day period. It appears in the diagram that the long-term variation shows at least three cycles during May through August 1979. This fact can be seen more clearly in the variation of filtered anomalies exhibited in Fig. 9b. The filtered anomalies indicate that the deep convection was enhanced over the equatorial SIO at the beginning of June, the latter half of July and the end of August. The convective activity was suppressed in the middle of May, the end of June and the early August. By comparing Fig. $9 b$ with $9 a$, one can see that the band-pass filter applied in this study well describes the long-term, intraseasonal variation both in the sense of its phase and amplitude.

The composite analysis in this study was carried out by using the time series shown in Fig. 9b. First, we have classified each cycle of the filtered variation into eight categories. Categories 1 and 5 were assigned to the time when the anomaly reaches the maximum and the minimum, respectively. Category 3 denotes the transition from positive anomalies to negative ones and Category 7 stands for the transition from negative to positive. Categories 2, 4, 6 and 8 were assigned to the intermediate times. Since the one cycle of this mode corresponds to about 30 - to 40 days of duration, the interval between each category is equivalent to about 4- to 5 days. The filtered variations of other variables were composited referring to the above categories. Figs. $10 \mathrm{a}$ through $10 \mathrm{e}$ represent the horizontal distributions of thus composited anomalies of $I_{c}$ for Category 1 through Category 5. The positive anomalies are shaded in these diagrams, indicating the area where the deep convective activity is enhanced due to the 30 - to 40 day, intraseasonal variation.

The horizontal distributions of the anomalies at Category 1 is exhibited in Fig. 10a. As mentioned above, this category corresponds to the time when the activity is most enhanced over the equatorial SIO. Naturally the positive anomalies take place over SIO in this figure with the local maximum located around $\left(5^{\circ} \mathrm{S}, 90^{\circ} \mathrm{E}\right)$. The positive area also extends eastward over the Indonesian Islands along the equator. The enhanced convective activity can be also seen over the Tibetan Plateau and the East China Sea. In contrast, quite distinct negative anomalies appear over the South China Sea and the head Bay of Bengal. The distribution shows that the deep convection is considerably suppressed at this stage over the Southeast Asia ranging from northeastern India through the Philippines. It is also notable that the suppressed condition occurs in the belt extending from the Philippines to the equatorial central Pacific. The configuration of this belt coincides with the mean location of the cloud belt associated with ITCZ during northern summer. It seems to suggest that the activity of ITCZ over the western Pacific also becomes weakened at this stage. Moreover, the configuration of the convective activity around Bay of Bengal resembles the characteristic distribution of the rainfall during break monsoon over India. We shall discuss this aspect later in this section.

Fig. 10b represents the composited distribution of the anomalies roughly 5 days after the previous figure. The enhanced condition still appears over SIO and the Indonesian Islands. However, when one looks into the situation over the Bay of Bengal, it can be seen that the area of the enhanced activity spreads northward. At the same time, the enhanced area around the Tibetan Plateau to the East China Sea also expands its coverage and shows the tendency to come down southward. Over the western Pacific to the east of the Philippines, the convective activity turns into the enhanced condition at this stage. It also appears that the suppressed area over the Timor Sea to the northwest of Australia shows westward expansion along the Indonesian Islands.

The above westward progression of the convective activity over SIO can be clearly seen in Figs. 10c and 10d which represent the composited distributions for Category 3 and Category 4 , respectively. Through these figures it emerges that the suppressed area which is originally located over Timor Sea at Category 1 progresses westward along the Indonesian Islands and brings the suppressed condition into SIO. It has been also noticed that this westward progression mainly appears to the west of Australian continent. This aspect corresponds to the westward propagation which we have seen in Fig. 8 before. In the previous Fig. 8, we have seen that the convective anomaly tends to propagate westward along the equator to the west of $140^{\circ} \mathrm{E}$, while it tends to move eastward to the east of $160^{\circ} \mathrm{E}$. Here, in Fig. 10, we can also see the indication of the eastward propagation to the east of Australia.

As for the situation around Bay of Bengal in Figs. $10 \mathrm{c}$ and $10 \mathrm{~d}$, it is clear that the convectively enhanced area progresses northward toward the head Bay. Simultaneously, the en- 


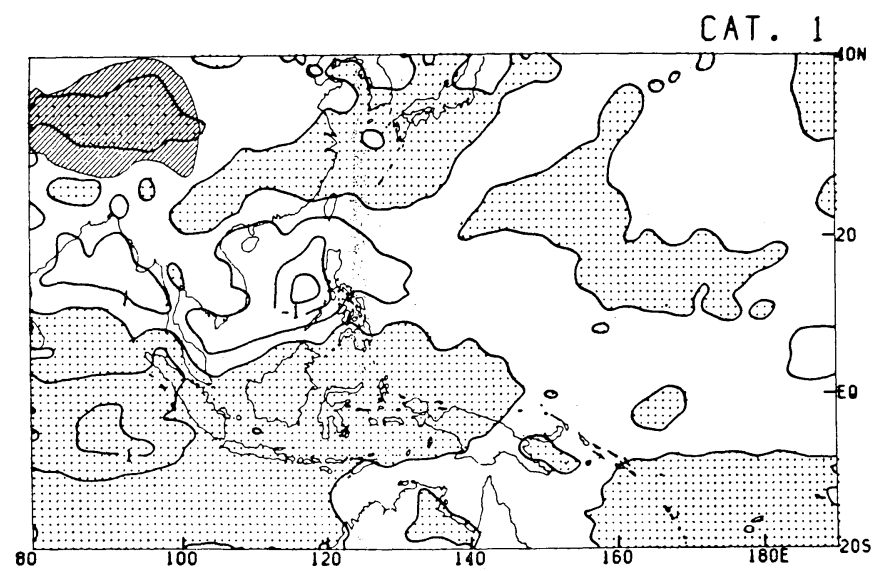

(a)

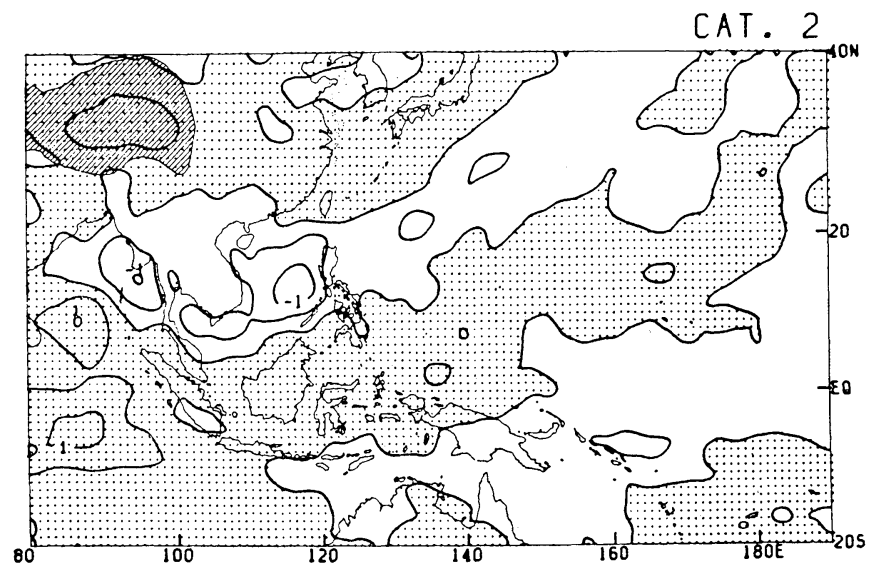

(b)

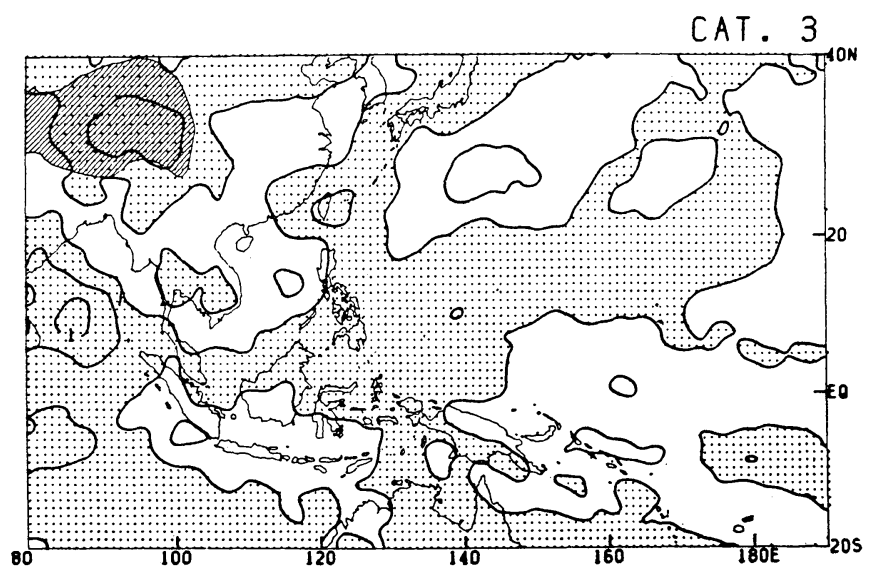

(c)

Fig. 10 (Continued) 


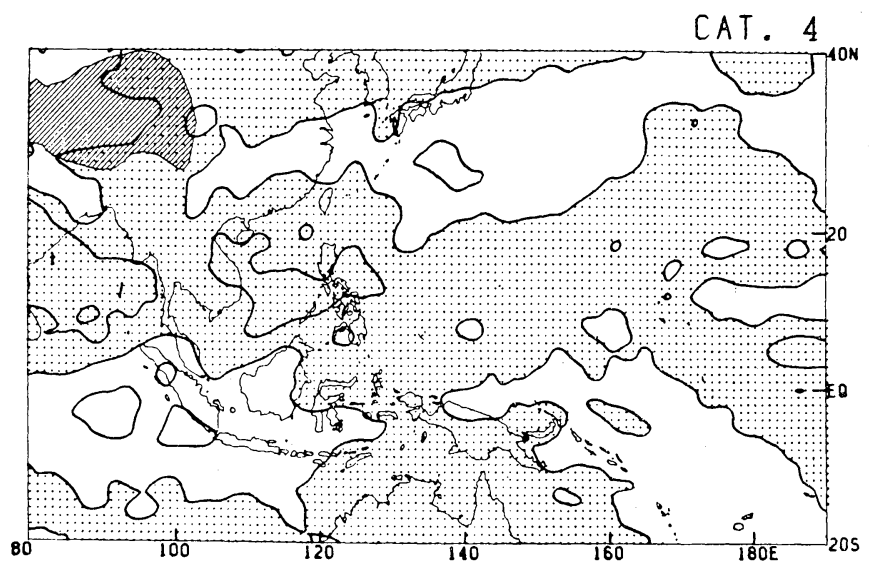

(d)

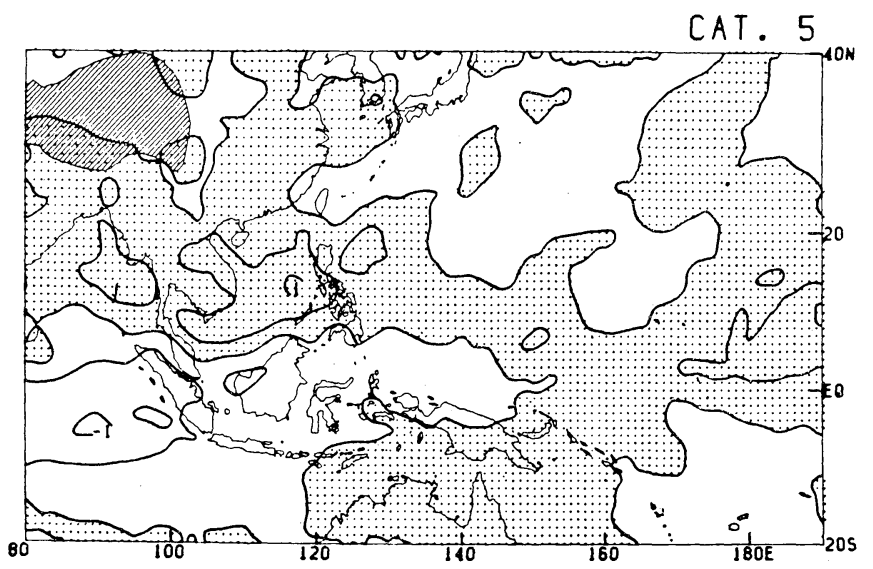

(e)

Fig. 10 Horizontal distributions of the composited anomalies of $I_{c}$ for Category 1 (a) through Category 5 (e). Contours are drawn at every 0.5 units and the positive anomalies are shaded.

hanced activity situated over Tibetan Plateau appears to come down southward through the southeastern part of the Plateau. At Category 4 shown in Fig. 10d, both areas are about to merge each other over the head Bay of Bengal. Keeping pace with this evolution, the suppressed condition over Indo-China through South China Sea becomes increasingly weaker and turns into the enhanced condition in Category 4. Over the western Pacific, one can also see that the northward-progressing enhanced area from the Indonesian Islands and the southward-progressing one from the East China Sea meet at around $15^{\circ}$ to $20^{\circ} \mathrm{N}$.

Fig. 10e represents the composited horizontal distribution of the anomalies at the stage when the convective activity is most suppressed over SIO. At this stage, Category 5, the enhanced condition appears over Southeast Asia ranging from northeastern India through the South China Sea to the Philippines. In contrast, the area over Tibetan Plateau generally shows the suppressed condition. The suppressed condition is intense over SIO and extends eastward over the Indonesian Islands. The configuration of these enhanced- and suppressed area over Southeast Asia shows the close resemblance to the cloudiness distribution during the active monsoon over India investigated by Hamilton (1977). In his results it is discussed that the strong cloudiness occurs over India, Bay of Bengal through western Burma during active monsoon and it is flanked by clear 
skies to the north and south. His results also shows the increased cloudiness over South China Sea and the Philippines. The agreement between the present analysis and his cloudiness distribution strongly suggests that Category 5 of this study corresponds to the active monsoon phase, while the previous Category 1 corresponds to the break monsoon over India.

Fig. 10e also shows the enhanced deep convective activity over the western Pacific to the east of the Philippines. The enhanced activity also takes place over the tropical central Pacific around the dateline. It can be seen that the enhanced area forms an east-west oriented belt between these two regions. This situation is nearly opposite to the one at Category 1 shown in Fig. 10a. The location of the enhanced convective belt in the present situation well coincides with the mean location of the convective belt which we have seen in Fig. 1 in the previous section. Since this mean convective belt is likely to be associated with the ITCZ during northern summer, it suggests that the activity of the ITCZ over the western Pacific is also intensified at this stage due to the 30 - to 40 day mode of the intraseasonal variation. Although the distributions for Category 6 through Category 8 are not shown in this paper, it turned out that the similar sequences occur as in Category 2 through Category 4 with the opposite sign of anomalies.

The above behavior of the convective cloud systems discussed with Fig. 10 well elucidates the characteristic features appeared in the latitudinal distribution discussed with Fig. 7 in the previous subsection. Through the time sequences in Fig. 10, it emerges that the repetitive northward progression is carried out by the cloud system which bears inter-regional scale. Such cloud system starts its progression at the latitude connecting the equatorial SIO and the Indonesian Islands. The southward progression which also appeared in Fig. 7 seems due to the migration of the convective areas from the Tibetan Plateau and the East China Sea. One may have noticed that the southward-moving convective area did not always appear en bloc over the east Asia compared with the appearance of the northward-moving counterpart over the Bay of Bengal in Fig. 10. Considering that the southward-moving component can be clearly recognized in Fig. 7, the above situation might imply the existence of the regional influence on the convective activity due to the large-scale orography ranging from Tibetan Plateau to east- ern China. In any case, both progressions tend to meet at the latitude around $15^{\circ} \mathrm{N}$ to $20^{\circ} \mathrm{N}$ at Category 5, forming the east-west oriented convective belt which ranges from northeastern India through the western Pacific. As a result, the situation at Category 5 shows the considerably enhanced cenvection over the head Bay of Bengal and the South China Sea, while the activity is definitely suppressed over SIO and the Tibetan Plateau. It also indicates the outof-phase relationship between the former areas and the latter ones.

As for the relationship between the Indian summer monsoon and the intraseasonal variation of the convective activity, we have discussed that the Category 5 in the above composite is likely to represent the situation of the active monsoon, while Category 1 corresponds to the break monsoon. Before concluding this section, we shall examine this aspect in the variation of the low-level monsoonal flow. Figs. 11a and 11b represent the horizontal distribution of the composited anomaly vectors of the wind at $850 \mathrm{mb}$ level for Category 1 and Category 5, respectively. The wind variation was compiled from the FGGE level III-b data set produced by ECMWF. The composite analysis of the wind was performed in the same way as we have done to the convective activity.

In Fig. 11a, one can see that the intense easterlies take place over the Indian subcontinent and the Arabian Sea. It means that the low-level monsoon westerly is in fact weakened, or even reversed, at Category 1 . On the other hand, the intense westerlies appear around India in Fig. 11b, indicating that the monsoon flow is intensified at Category 5. In addition, this figure also shows the easterlies along the southern periphery of the Tibetan Plateau. The configuration of these easterlies and westerlies to the south of the Plateau indicates that the monsoon trough is also intensified at Category 5 over the region ranging from northern India to the head Bay of Bengal. These contrasting situations appeared in Fig. 11a and $11 \mathrm{~b}$ verify our previous discussion that the Category 5 represents the active monsoon and Category 1 represents the break monsoon over India.

Figs. $11 \mathrm{a}$ and $11 \mathrm{~b}$ also show many interesting situations over the much more wider area rather than just the vicinity of India. For example, one can see the systematic distribution of the anomalies over SIO in the middle latitude of the southern hemisphere. At Category 1 in Fig. 


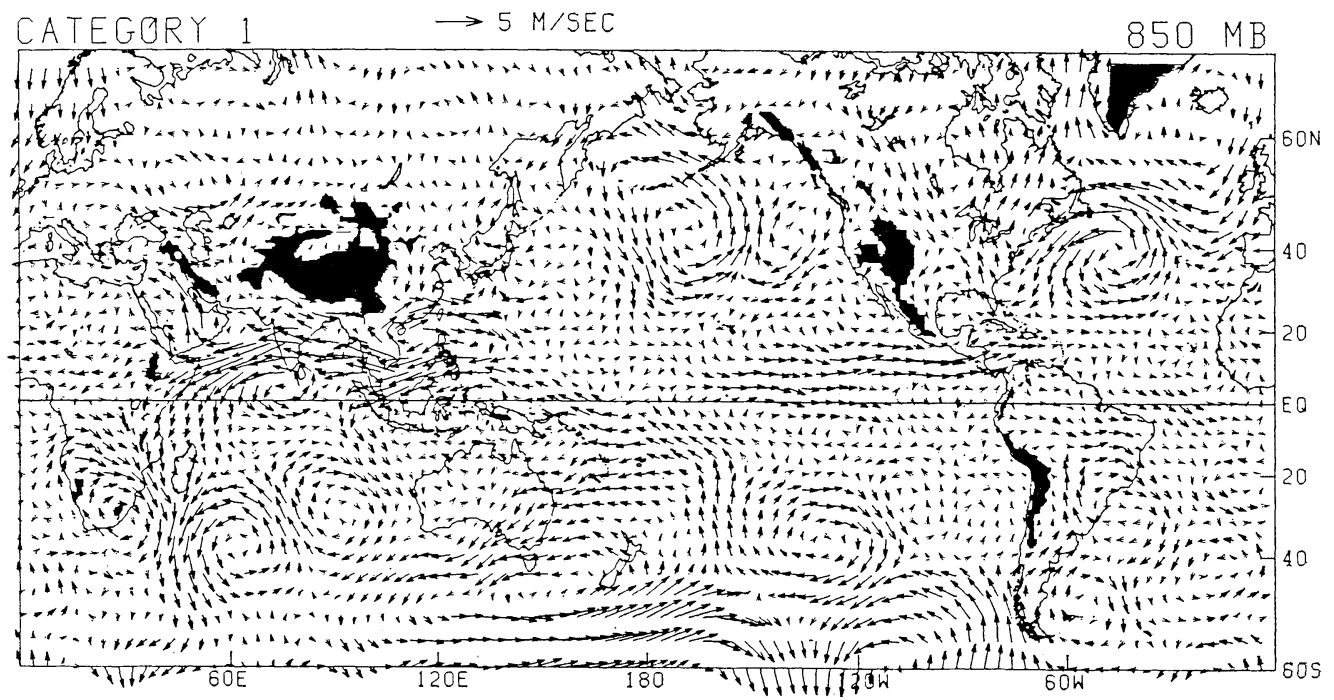

(a)

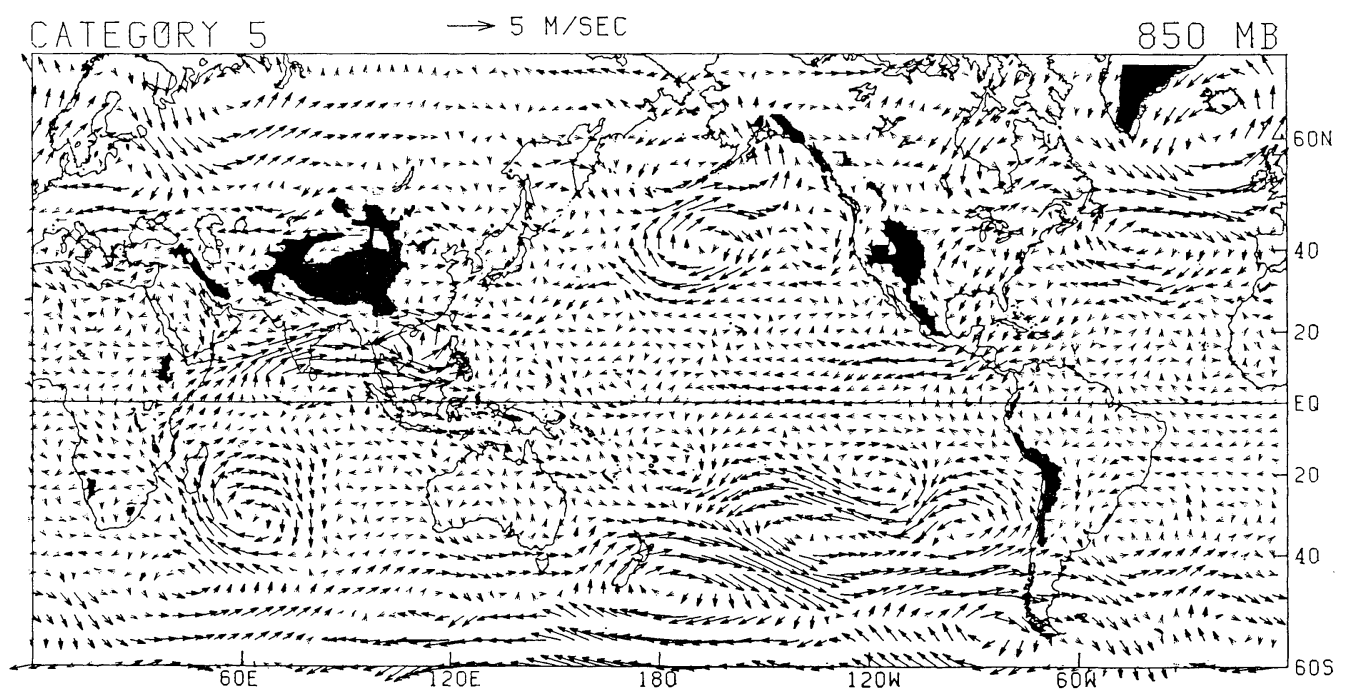

(b)

Fig. 11 Horizontal distributions of the composited wind anomalies at $850 \mathrm{mb}$ level for Category 1 (a) and Category 5 (b).

11a, an anticyclonic circulation appears to the southeast of Madagascar accompanied with the cyclonic circulations to its east and west. Northerly anomalies are prevailing off the east coast of Africa and to the south of Madagascar. On the contrary, the intense southerlies appear over the same region at Category 5 shown in Fig. $11 \mathrm{~b}$. They are associated with the distinct cyclonic circulation to the southeast of Mada- gascar. It is interesting that there is no sign of the intensification of the Mascarene High at this stage of active monsoon. Although the Mascarene High clearly appears along $30^{\circ} \mathrm{S}$ over SIO in the time mean flow (not shown) and it is said to be an important part to form the large-scale monsoonal circulation, the present result seems to suggest that it is not the in situ intensification of the Mascarene High which is 
responsible for the active monsoon phase due to the 30- to 40 day mode of the intraseasonal variation.

Systematic distributions of the anomalies appear on the other part of the globe as well. One can see in Fig. 11b that the intensification of the anticyclonic circulation occurs over the northern Pacific and northern Atlantic. Over the eastern equatorial Pacific, the easterlies appear along and to the north of the equator, occupying nearly the opposite side of the globe with respect to the westerlies around India. Over the Eurasian continent, a large-scale trough appears to the north of Caspian Sea. More detailed analysis on these global changes of the atmospheric circulation is likely to reveal many interesting aspects associated with the intraseasonal variation of the monsoon.

\section{Summary and remarks}

In this study we have investigated the largescale behavior of a mass of deep convective clouds over the Southeast Asia and the western Pacific during northern summer of 1979. The seasonal evolution during this period was examined both in terms of the horizontal distribution and the latitudinal behavior. It turned out that the monthly mean distribution of the deep convective activity devised in this study well describes the situations which have, in many past investigations, been inferred from the cloudiness distribution. The month-to-month change of the distribution has revealed the northward advance of the convective area along the Indo-China peninsula, the formation of the convective belt across the Southeast Asia which is connected with the so-called "Bai-u front" near Japan, and the northward shift of the east-west oriented convective belt associated with ITCZ over the western Pacific. The monthly mean distribution also showed the existence of the two parallel convective belts on both sides of the equator over the central Pacific. During the months when the monsoon westerly prevails, the distribution of the activity over Southeast Asia seemed to suggest the influence of the large-scale orography which causes the suppression of the convective clouds in the lee-side of Burmese and Vietnamese mountains.

The northward advance of the convective area during the early summer was more clearly demonstrated in the latitude-time section along the western coast of Indo-China. Over this region, the initial advance occurs during May. The convective area reaches the southeastern periphery of the Tibetan Plateau in June, nearly in time with the onset of Indian monsoon. After this period, the northward advance comes to a halt and the intense convective activity prevails over the wide latitudinal range to the south of the Plateau. However, it has been also noticed that there is a major intraseasonal variation of the activity which appears in the form of the repetitive progression from the South Indian Ocean. The time interval of these progressions turned out to be about a month or so.

The latitude-time section along the meridian running through the western Pacific has shown somewhat different aspect. It revealed the formation of the two separate convective areas during June through July. The northern one appears at the latitude close to the East China Sea, bringing the Bai-u rain over Japan and its vicinity. The southern one appears at the tropical latitudes in association with the ITCZ over the western Pacific. They are separated by the area with the suppressed convective activity apparently caused by the prevalence of the subtropical anticyclone. It was noted that both of the above convective areas tend to behave simultaneously. For instance, they both tend to be intensified nearly at the same time and when the Bai-u convective system shifts northward, another one associated with ITCZ also shows northward advance.

The intraseasonal variation mentioned above was investigated by applying the band-pass filter which can pick up the fluctuation with 30 - to 40 day period. The latitude-time section of the filtered anomalies along the west coast of IndoChina has confirmed the repetitive northward progression associated with the $30-$ to 40 day mode. The progression starts at the latitude around the equatorial South Indian Ocean and its phase speed appeared to be about $1^{\circ}$ latitude/ day. This behavior corresponds to the one which was discussed previously by Yasunari (1979) and Sikka and Gadgil (1980) in terms of the cloudiness distribution. However, the present analysis has revealed the fact that the above mode also shows the simultaneous southward progression from the Tibetan Plateau toward the head Bay of Bengal around $20^{\circ} \mathrm{N}$. Quite interestingly, the similar situation also appears in the behavior of the filtered anomalies over the western Pacific off the east coast of Asian continent. Here, the northward progression starts at the latitude close to Indonesian Islands and the southward pro- 
gression comes down from the East China Sea region. Both of them tend to meet at the latitude around $15^{\circ} \mathrm{N}$, close to the Philippines. Moreover, it turned out that the timing of these northward- and southward progressions over the western Pacific almost coincides with the timing of their counterpart over Indo-China.

The above synchronous latitudinal confluence of the convective activity over the wide longitudinal range seems to suggest the confluence of the two meridional circulation cells whose upward portions coincide with the two convective areas. Yasunari (1981) discussed the northward shift of the upward portion of Hadley cell associated with the $30-$ to 40 day mode. This study suggests that another upward portion comes down southward from the latitude of Tibetan Plateau and merges in each other over $15^{\circ}$ to $20^{\circ} \mathrm{N}$ at the stage of active monsoon.

Based on the findings discussed above, it was inferred that the $30-$ to 40 day mode of the deep convective activity bears an inter-regional scale both longitudinally and latitudinally. This aspect was investigated by making the composited horizontal distribution of the anomalies with respect to the 30 - to 40 day variation over the equatorial South Indian Ocean. When the convective activity is enhanced over this region, it was found that the enhanced activity also appears over the Indonesian Islands around the equator. The enhanced condition also takes place over the Tibetan Plateau and the East China Sea at the same stage. In contrast, the convective activity is suppressed over the area in between. The intense suppressed condition appears over the South China Sea and the Bay of Bengal. In addition, it turned out that the deep convection is also suppressed along the east-west oriented belt over the western Pacific which corresponds to the mean location of the cloud belt associated with ITCZ.

The composite analysis performed on the wind variations at $850 \mathrm{mb}$ level has proved that the above stage of the 30 - to 40 day mode corresponds to the break monsoon over India. The intense easterly anomalies are prominent over the Indian subcontinent at this time and the northerlies prevail along the east coast of Africa from the equator through the Mozambique channel. It also drew our attention that the westerlies are intensified over the tropical eastern Pacific at the same time when the easterlies appear over the Arabian Sea to the Philippines.

At the stage when the deep convective activity is most suppressed over the equatorial South Indian Ocean, it was found that the enhanced convection occurs over the Southeast Asia ranging from the northeastern India through the Philippines. The area over the Tibetan Plateau generally shows the suppressed condition at this time. The composite analysis of the wind anomalies again proved that the active monsoon appears over India at this stage. It was notable that the deep convective clouds are also enhanced simultaneously along the mean location of the cloud belt associated with ITCZ over the western- to central Pacific.

As for the transition from the break monsoon to the active monsoon situation, a series of the composited distributions have revealed that the simultaneous northward- and southward progressions of the convective area occur over the Southeast Asia and the western Pacific. At the time of the break monsoon over India, the enhanced convective area appears over the region ranging from the equatorial South Indian Ocean through the Indonesian Islands. Another convective area appears over the Tibetan Plateau and the East China Sea as we have discussed above. The sequence of the composited distributions has shown that the former area progresses northward over the Bay of Bengal and the western Pacific, while the latter area progresses southward. Both areas tend to merge each other at the latitude around $15^{\circ}$ to $20^{\circ} \mathrm{N}$ prior to the active stage of the Indian monsoon. Thus, at the stage of the active monsoon, we saw a wide, belt-shaped convective area ranging from the northeastern India through the South China Sea to the western Pacific.

Another interesting aspect we saw in the change of the composited distribution is that the convective activity has shown the westward progression over the equatorial South Indian Ocean to the west of Australia. The sequence of the distributions has revealed that the change from the enhanced convection to the suppressed one over the ocean south of the Bay of Bengal is caused by the intrusion of the suppressed area from the east. Similar situation occurs with the opposite sign accompanying the change from the suppressed condition to the enhanced one. This situation agrees with Cadet (1983)'s analysis in which he discussed that the westward propagation can be seen in the 20- to 40 day variation of the surface pressure and the wind intensity over the equatorial Indian Ocean. The present analysis has shown that such westward propa- 
gation in the convective activity tends to start from the Timor Sea region and to progress along the southern part of the Indonesian Islands. In addition, the longitude-time section along the equator in this study has also revealed that the convective anomaly due to the 30 - to 40 day mode tends to propagate eastward over the central Pacific to the east of Australian continent. Both Madden and Julian (1972) and Maruyama (1982) analyzed the disturbance of the 30- to 50 day period which shows the eastward propagation over the equatorial Pacific. The eastward propagation of the convective activity present in this study may reflect the passage of this kind of disturbances. However, the appearance of the westward propagation in this study to the west of Indonesia indicates that the 30- to 40 day intraseasonal variation should be viewed as a multi-mode system in which each mode has a mutual interrelationship with one another.

Considering the above aspects discussed in this study, it appears more and more likely that the intraseasonal variation of the Indian summer monsoon is closely linked with the atmospheric phenomena which bears more than a hemispheric scale. Krishnamurti and Subrahmanyam (1982) have already shown that there exists a $30-$ to 50 day mode in the wind variation at $850 \mathrm{mb}$ level by using MONEX wind data set. They also illustrated that the above mode manifests itself in the form of the east-west oriented trough/ridge system across the Indian Ocean which shows a steady meridional propagation from the equator towards northern India. We have examined the FGGE level III-b data on the global domain and found the evidences which indicate the global aspect of the 30- to 40 day mode as shortly discussed in the previous section. A more detailed analysis on this subject is under way and we shall discuss its result hopefully in the near future.

\section{Acknowledgement}

The author wishes to express his thanks to Dr. Ts. Nitta and anonymous reviewers, whose comments greatly improved the clarity of the paper. The calculations in this study were performed on the HITAC M-200H system of the Meteorological Research Institute. Thanks are due to Earthquake Research Institute of Tokyo University for providing us with the digital map data and to National Institute of Polar Research for developing its computer program.

\section{References}

Arakawa, H., 1959: Relation among beginning of dry season in Java, establishment of SW monsoon in India and onset of Bai-u in the Far East. Proc. IGU Reg. Conf. Japan 1957, 589592.

Asakura, T., 1979: Cloud distribution over east Asia during the summer monsoon season interpreted through satellite pictures. Geo Journal, 3, $147-152$.

Cadet, D., 1983: The monsoon over the Indian Ocean during summer 1975. Part II: Break and active monsoons. Mon. Wea. Rev., 111, 95-108.

FGGE Operations Report No. 8, 1981: Summer MONEX field phase report, WMO, $381 \mathrm{pp}$.

Hamilton, M. G., 1977: Some aspects of break and active monsoon over southern Asia during summer. Tellus, 29, 335-344.

Krishnamurti, T. N. and D. Subrahmanyam, 1982: The 30 to 50 day mode at $850 \mathrm{mb}$ during MONEX. J. Atmos. Sci., 39, 2088-2095.

Madden, R. A. and P. R. Julian, 1972: Description of global-scale circulation cells in the tropics with a 40-50 day period. J. Atmos. Sci., 29, 11091123.

Maruyama, T., 1982: Upper tropospheric zonal wind oscillation with a 30-50 day period over the equatorial western Pacific observed in cloud movement vectors. J. Meteor. Soc. Japan, 60, $172-182$.

Murakami, M., 1979: Large-scale aspects of deep convective activity over the GATE area. Mon. Wea. Rev., 107, 994-1013.

_- 1983: Analysis of the deep convective activity over the western Pacific and Southeast Asia. Part I: Diurnal variation. J. Meteor. Soc. Japan, 61, 60-76.

Murakami, T., 1976: Cloudiness fluctuations during the summer monsoon. J. Meteor. Soc. Japan, 54, $175-181$.

- 1980: Empirical orthogonal function analysis of satellite-observed outgoing longwave radiation during summer. Mon. Wea. Rev., 108, 205-222.

Ramage, C. S., 1971: Monsoon meteorology. New York, Academic Press, $296 \mathrm{pp}$.

, F. R. Miller and C. Jefferies, 1972: Meteorological atlas of the International India Ocean Expedition. Vol. 1: The surface climate of 1963 and 1964. National Science Foundation, U.S.A., 144. pp.

Rasmusson, E. M. and T. H. Carpenter, 1982: Variations in tropical sea surface temperature and surface wind fields associated with the Southern Oscillation/El Nino. Mon. Wea. Rev., 110, 354 384.

Sadler, J. C., L. Oda and B. J. Kilonsky, 1976: Pacific Ocean cloudiness from satellite observa- 
tions. Rept. UHMET 76-01, Department of Meteorology, University of Hawaii, $137 \mathrm{pp}$.

Sikka, D. R. and S. Gadgil, 1980: On the maximum cloud zone and the ITCZ over Indian longitudes during the southwest monsoon. Mon. Wea. Rev., 108, 1840-1853.

Winston, J. S. and A. F. Krueger, 1977: Diagnosis of the satellite-observed radiative heating in relation to the summer monsoon. Pure Appl. Geophys., 115, 1131-1144.

Yasunari, T., 1979: Cloudiness fluctuations associated with the northern hemisphere summer monsoon. J. Meteor. Soc. Japan, 57, 227-242. 1980: A quasi-stationary appearance of
30 to 40 day period in the cloudiness fluctuations during the summer monsoon over India. $J$. Meteor. Soc. Japan, 58, 225-229.

, 1981: Structure of an Indian summer monsoon system with around 40-day period. $J$. Meteor. Soc. Japan, 59, 336-354.

Yoshino, M. M., 1965: Four stages of the rainy season in early summer over east Asia (Part I). J. Meteor. Soc. Japan, 43, 231-245.

, 1966: Four stages of the rainy reason in early summer over east Asia (Part II). $J$. Meteor. Soc. Japan, 44, 209-217. ed., 1971: Water balance of monsoon Asia. Univ. of Tokyo Press, 308 pp.

\title{
西太平洋および東南アジア地域における深い積雲対流活動の解析
}

\section{第 2 部＼cjkstart北半球の夏にみられる季節変化と季節内変動}

\author{
村上勝人 \\ 気象研究所
}

深い積雲群の振舞にみられる季節変化和よび季節内変動を，当論文の第 1 部において提唱された活動度示数を 用いて調べた。1979年 5 月から 8 月の各月に执いて作成された月平均の活動度分布には，従来雲量分布や長波放 射量から推測されているにすぎなかった積雲活動の季節的な特徵がよくあらわれている。分布の緯度方向への変 動に敃いては，東南アジア地域に打ける積雲活動の活発な領域の北進，梅雨をもたらす積雲活動域の形成，拈よ び西太平洋上に拉ける熱帯収束帯にともなら帯状の積雲活動域の北への変位などが明瞭にあらわれている。

この積雲活動度の緯度一時間変化図に和いては周期 30 日から 40 日程度の大きな季節内変動の存在が明らかにな った。インドシナ半島初よびベンガル湾方面に叔いてはこの変動は南インド洋赤道付近からくり返し進行してく る様相を示す。時間変動に関するバンドパス・フィルターを用いてさらに詳細な解析を行なったところ,変動のな かにはチベット高原方面から南進してくる成分もあることが分かった。さらに，同様の状況が西太平洋上に拉い ても生じていることも明らかになった。 $850 \mathrm{mb}$ 面に拉ける風の変動に関するコンポジット解析の結果によれば, この 30-40 日周期変動はインドにおけるモンスーンの活発／休止のサイクルに伴なって変動している。インド上 空でモンスーン西風が最も強化された時，活発な積雲活動域はインド北東部からフィリッピン諸島をつらねる領 域にあらわれる。これと対照的に，インド洋赤道付近やチベット高原では積雲活動は抑制されている。さらに当 解析の結果によれば，この時期には西太平洋上の熱帯収束帯に伴なら積雲活動も活発化していることが明らかに なった。 